\title{
生き残りパスを利用した雑音予測による雑音白色化機能 を備えたビタビ復号法の検討
}

\author{
A Study on a Viterbi Decoding Method with a Noise Whitening Function \\ by Noise Prediction using its Survived Paths
}

正会員池谷＼cjkstart章 ${ }^{\dagger}$, 正会員 小林 正 明 ${ }^{\dagger}$

Akira Iketani ${ }^{\dagger}$ and Masaaki Kobayashi ${ }^{\dagger}$

\begin{abstract}
This paper describes a method of eliminating the auto correlation of equalized noises to have the optimum performance of a Viterbi decoder designed for white noise. This elimination is performed by subtracting predicted noises from an arriving equalized noise. This predicted noise is generated by using both coefficients calculated from auto correlation of the equalized noises and noises corresponding to survived paths. A correctly predicted noise reduces an arriving equalized noise on average, so the error rate becomes lower. A Viterbi decoder with a noise whitening function reduced the number of errors to about $1 / 6$ of those of a conventional Viterbi decoder's for an experimental digital video cassette recorder. The conditions of the experiments were: relative tap e-to-head speed of $7.5 \mathrm{~m} / \mathrm{s}$, recording rate of $40.5 \mathrm{Mb} / \mathrm{s}$, and $8 / 12$ code whose minimum run length was limited to 2 (in NRZL notation) combined with EPR 4, and four coefficients for noise prediction.
\end{abstract}

キーワード：ディジタル，記録，ビタビ復号，雑音白色化

\section{1. ま え がき}

近年，家庭用ディジタル VTR や磁気ディスクのよう に, 種々のディジタル記録機器が消費者市場に投入されて おり，これらのシステムにも従来のビットごとの復号法に 代わり，ビタビ復号法が導入されている.

ビタビ復号法は, よく知られているように, 入力データ に対応する最尤系列を推定して復号を行う方式である。そ して，これまでに通信を初めとして種々の分野で多くの研 究が行われており，ディジタル記録の分野においても， NRZL と NRZI 記録符号に適用した場合の誤り率特性の 解析が行われている112).

さらに，家庭用ディジタルVTRのような波形干渉が無 視できない高密度記録において, 必要になる波形等化によ つて生じる $S / N$ 劣化と, 復号器入力雑音のサンプル值間 の相関が，更に誤り率を低下させるという解析結果が報告 されている3).

そこで本論文では，波形等化によって生じる雑音の相関 によって生じるビタビ復号器の誤り率の劣化を改善するた めに，最近注目されている NRZL 表記で同一 2 進值の最

1989 年 9 月 5 日, 特許公開公報 特開平 1-222541

1998 年 9 月 16 日受付, 1998 年 12 月 8 日再受付, 1999 年 2 月 2 日採録

$\dagger$ 松下電器産業株式会社 AVC 商品開発研究所

(テ 571-8501 門真市大字門真 1006, TEL 06-6900-9285)

AVC Products Development Laboratories, Matsushita Electric Industrial Co., Ltd.

(1006, Oaza-Kadoma, Kadoma-shi, Osaka 571-8501, Japan)
小連続ビット数 $d=2$ の RLL (Run Length Limited) 符号 を磁気記録に用いる場合の雑音の相関除去方法と，これを 用いたビ夕ビ復号器を示す。さらに，雑音の相関を除去し ない従来のビ夕ビ復号器との誤り率の比較も行う.

\section{2. 磁気記録・再生系の特徵}

磁気記録の場合，記録再生系は微分特性を示すから，0 と 1 よりなる 2 進記録符号系列を $\left\{b_{k}\right\}$ とすると，理想的 な再生出力系列 $\left\{x_{k}\right\}$ は ( 1 )式で与えられる.

$$
x_{k}=b_{k}-b_{k-1}
$$

ここで，孤立再生波形を $u(t)$ とし，そのサンプル值を $u_{i}$ $=u\left(i T_{R}\right)$ とすると, 実際の受信系列 $\left\{y_{k}\right\}$ は (2) 式で表さ れる、ただし， $T_{R}$ は記録符号の 1 ビット長である。

$$
y_{k}=\sum_{i=-\infty}^{\infty} x_{k-i} \cdot u_{i}+n_{k}^{\prime}
$$

また， $n_{k}^{\prime}$ は，読出し点での雑音のサンプル値である。 (2) 式を周波数成分で書き換えると（3)式になる。なお， $X(f), U(f), N^{\prime}(f)$ おょび $Y(f)$ は，それぞれ $x_{k}, u_{i}, n_{k}^{\prime}$ および $y_{k}$ の連続時間関数である $x(t), u(t), n^{\prime}(t)$ および $y(t)$ のフーリエ変換により得られる。

$$
Y(f)=X(f) \cdot U(f)+N^{\prime}(f)
$$

高密度記録では，波形干渉量は著しく大きく，波形等化 により波形干渉を除去しなければならない。このとき， (3)式からわかるように, 再生過程で減衰した高周波数成 分を補正する $1 / U(f)$ の特性を有する波形等化を行うこと 
により，(4)式に示す等化出力 $Z(f)$ が得られる.

$$
Z(f)=X(f)+\frac{N^{\prime}(f)}{U(f)}=X(f)+N(f)
$$

ここに, $N(f)=N^{\prime}(f) / U(f)$ は等化雑音である.

再生系の周波数特性 $U(f)$ は, 高周波隇衰特性であるか ら，この逆特性 $1 / U(f)$ は高周波強調特性になる。したが って，(4) 式に扔ける等化雑音 $N(f)$ は高周波強調特性を 示す．記録密度が高くなればなるほど等化雑音の高周波強 調度は強まる。

\subsection{RLL 符号に対する等化雑音低減方式}

RLL 符号は高密度記録に重要な役割を果たす。しかし， $d$ が大きくなるにつれ RLL 符号の圥長度も増し, 等化帯 域が広がる結果, 高周波等化雑音の増加による誤り率特性 の大きな劣化を招く.

したがって，高密度記録のために $d$ が 2 以上の RLL 符 号を用いる必要がある場合には, ビ夕ビ復号器を用いる場 合であっても，このような等化雑音の低減は不可欠であ る。

ところで, $d$ が 2 以上の RLL符号の場合, 同一 2 進値 は必ず 2 ビット以上連続するという明らかな相関を持つの で，この RLL符号に対して，例えば，適当な $L$ 次のアダ マール変換を一例とする直交変換を行うと, 直交変換後の 独立成分の数は $L$ よも少なくなり得る.

すなわち， $d$ が 2 以上の RLL 符号に直交変換を施すこ とで，等化雑音の影響がより少ない独立な直交変換成分を 選択して用いることができれば，等化雑音の影響が低減さ れ，誤り率の増加が抑制される。

以下, $d=2$ の RLL符号と 4 次のアダマール変換を一 例として用い，直交変換により RLL符号に対する等化雑 音が低減されることを示す．この結果，4個のアダマール 成分の 3 成分だけで, $d=2$ の RLL符号に扔ける 2 進パ ターンがすべて復元される.

\section{2 アダマール変換を用いた等化雑音低減例}

例えば， $d=2$ を満足するビット列に現れる 5 ビットパ ターンBと,この 5 ビットパターン B に対する(1)式に よって得られる理想再生出力 $x$ は, 表 1 に示す 16 通りで ある.な抢，再生出力は \pm 1 に正規化されているものとす る.

表 2 は, 表 1 の理想再生出力 $x$ と, $x$ に( 5 )式で与え られる 4 次のアダマール変換を行って得られる成分を示 す。

$$
\left.\begin{array}{l}
h_{0}=x_{0}+x_{1}+x_{2}+x_{3} \\
h_{1}=x_{0}+x_{1}-x_{2}-x_{3} \\
h_{2}=x_{0}-x_{1}-x_{2}+x_{3} \\
h_{3}=x_{0}-x_{1}+x_{2}+x_{3}
\end{array}\right]
$$

ウォルシュアダマール変換は, 変化の少ない成分から変 化の多い成分にわたるスペクトル分解能を有する ${ }^{4)}$.つま り，（5)式における $h_{0}$ は最低周波数成分を表し， $h_{1}, h_{2}$ の 順に高い周波数成分を表し， $h_{3}$ は最高周波数成分を表す。
表 1 記録ビット列と理想再生信号 Recording 5 bit-pattern and ideal playback signal.

\begin{tabular}{r|r|r|r|r|r|r|r|r|r}
\hline \multirow{2}{*}{ No. } & \multicolumn{7}{|c|}{$B$} & \multicolumn{5}{|c}{$x$} \\
\cline { 2 - 10 } & $b_{0}$ & $b_{1}$ & $b_{2}$ & $b_{3}$ & $b_{4}$ & $x_{0}$ & $x_{1}$ & $x_{2}$ & $x_{3}$ \\
\hline 0 & 0 & 0 & 0 & 0 & 0 & 0 & 0 & 0 & 0 \\
\hline 1 & 0 & 0 & 0 & 0 & 1 & 0 & 0 & 0 & 1 \\
\hline 2 & 0 & 0 & 0 & 1 & 1 & 0 & 0 & 1 & 0 \\
\hline 3 & 0 & 0 & 1 & 1 & 0 & 0 & 1 & 0 & -1 \\
\hline 4 & 0 & 0 & 1 & 1 & 1 & 0 & 1 & 0 & 0 \\
\hline 5 & 0 & 1 & 1 & 0 & 0 & 1 & 0 & -1 & 0 \\
\hline 6 & 0 & 1 & 1 & 1 & 0 & 1 & 0 & 0 & -1 \\
\hline 7 & 0 & 1 & 1 & 1 & 1 & 1 & 0 & 0 & 0 \\
\hline 8 & 1 & 0 & 0 & 0 & 0 & -1 & 0 & 0 & 0 \\
\hline 9 & 1 & 0 & 0 & 0 & 1 & -1 & 0 & 0 & 1 \\
\hline 10 & 1 & 0 & 0 & 1 & 1 & -1 & 0 & 1 & 0 \\
\hline 11 & 1 & 1 & 0 & 0 & 0 & 0 & -1 & 0 & 0 \\
\hline 12 & 1 & 1 & 0 & 0 & 1 & 0 & -1 & 0 & 1 \\
\hline 13 & 1 & 1 & 1 & 0 & 0 & 0 & 0 & -1 & 0 \\
\hline 14 & 1 & 1 & 1 & 1 & 0 & 0 & 0 & 0 & -1 \\
\hline 15 & 1 & 1 & 1 & 1 & 1 & 0 & 0 & 0 & 0 \\
\hline
\end{tabular}

表 2 再生出力のアダマール変換

Adamard transform sequencies for playback signals.

\begin{tabular}{c|r|r|r|r|r|r|r|r}
\hline \multirow{2}{*}{ No. } & \multicolumn{5}{|c|}{$x$} & \multicolumn{4}{c}{$H$} \\
\cline { 2 - 9 } & $x_{0}$ & $x_{1}$ & $x_{2}$ & $x_{3}$ & $h_{0}$ & $h_{1}$ & $h_{2}$ & $h_{3}$ \\
\hline 0 & 0 & 0 & 0 & 0 & 0 & 0 & 0 & 0 \\
\hline 1 & 0 & 0 & 0 & 1 & 1 & -1 & 1 & -1 \\
\hline 2 & 0 & 0 & 1 & 0 & 1 & -1 & -1 & 1 \\
\hline 3 & 0 & 1 & 0 & -1 & 0 & 2 & -2 & 0 \\
\hline 4 & 0 & 1 & 0 & 0 & 1 & 1 & -1 & -1 \\
\hline 5 & 1 & 0 & -1 & 0 & 0 & 2 & 2 & 0 \\
\hline 6 & 1 & 0 & 0 & -1 & 0 & 2 & 0 & 2 \\
\hline 7 & 1 & 0 & 0 & 0 & 1 & 1 & 1 & 1 \\
\hline 8 & -1 & 0 & 0 & 0 & -1 & -1 & -1 & -1 \\
\hline 9 & -1 & 0 & 0 & 1 & 0 & -2 & 0 & -2 \\
\hline 10 & -1 & 0 & 1 & 0 & 0 & -2 & -2 & 0 \\
\hline 11 & 0 & -1 & 0 & 0 & -1 & -1 & 1 & 1 \\
\hline 12 & 0 & -1 & 0 & 1 & 0 & -2 & 2 & 0 \\
\hline 13 & 0 & 0 & -1 & 0 & -1 & 1 & 1 & -1 \\
\hline 14 & 0 & 0 & 0 & -1 & -1 & 1 & -1 & 1 \\
\hline 15 & 0 & 0 & 0 & 0 & 0 & 0 & 0 & 0 \\
\hline
\end{tabular}

\section{3. 信号検出方式}

表 2 からわかるように, 各理想再生出力は, それぞれに 対応する 3 個のアダマール成分を参照するだけで一意に特 定される。したがって，波形等化によって高周波雑音が大 きくなる場合, 最高周波数成分 $h_{3}$ を参照することなく各 $\left(x_{0}, x_{1}, x_{2}, x_{3}\right)$ を復元することで，等化による雑音の影響 
を低減できる. 以下, $\left(h_{0}, h_{1}, h_{2}\right)$ のみを用いて, $\left(x_{0}, x_{1}\right.$, $\left.x_{2}, x_{3}\right)$ を復元する方法について記す.

(5)式に示した $h_{1}$ 成分と, 変形成分 $h_{12}$ はそれぞれ (6)式で表され, 表 3 のようになる. 表 3 から, 各成分 $\left(h_{1}, h_{12}\right)$ は互いに異なる $\left(x_{0}, x_{1}, x_{2}, x_{3}\right)$ に対応することが わかる。

$$
\left.\begin{array}{l}
h_{12}=2 h_{0}-h_{2} \\
h_{1}=x_{0}+x_{1}-x_{2}-x_{3} \\
h_{12}=x_{0}+3 \cdot x_{1}+3 \cdot x_{2}+x_{3}
\end{array}\right]
$$

したがって，( $\left.h_{1}, h_{12}\right)$ を識別することで，これに対する $\left(x_{0}, x_{1}, x_{2}, x_{3}\right)$ を復号できる。ここで, $p_{k}, p_{k+1} を(7)$ 式の ように定める.

$$
\left.\begin{array}{l}
p_{k}=x_{0}+2 \cdot x_{1}+x_{2} \\
p_{k+1}=x_{1}+2 \cdot x_{2}+x_{3}
\end{array}\right]
$$

(6)式と ( 7 )式とから，(8)式が得られる.

$$
\left.\begin{array}{l}
h_{1}=p_{k}-p_{k+1} \\
h_{12}=p_{k}+p_{k+1}
\end{array}\right]
$$

(8) 式から， $\left(h_{1}, h_{12}\right)$ は $\left(p_{k}, p_{k+1}\right)$ に対する 2 次の直交 変換によって得られ, $\left(h_{1}, h_{12}\right)$ を用いた復号と $\left(p_{k}, p_{k+1}\right)$ を用いた復号とは等価であることがわかる．つまり，( $p_{k}$, $\left.p_{k+1}\right)$ を用いて復号しても，( $\left.h_{0}, h_{1}, h_{2}\right)$ の 3 成分しか用い ていないので，合理的に高周波雑音を排除できる.

(7) 式からわかるように, $\left\{p_{k}\right\}$ は $\left\{x_{k}\right\}$ の連続する 3 要 素から順次得られ， $p_{k}$ の一般式は (9) 式で与えられる.

$$
p_{k}=x_{0}+2 \cdot x_{1}+x_{2}
$$

さらに，(9)式を遅延演算子 $D$ を用いて書き換えると， (10)式となる .

$$
D=\exp \left(-j 2 \pi f T_{R}\right)
$$

表 3 . 変形アダマール成分

Modified Adamard sequencies.

\begin{tabular}{r|r|r|r|r|r|r}
\hline \hline \multirow{2}{*}{ No. } & \multicolumn{7}{|c|}{$H$} & \multicolumn{2}{|c}{$H^{\prime}$} \\
\cline { 2 - 7 } & $h_{0}$ & $h_{1}$ & $h_{2}$ & $h_{3}$ & $h_{1}$ & $h_{12}$ \\
\hline 0 & 0 & 0 & 0 & 0 & 0 & 0 \\
\hline 1 & 1 & -1 & 1 & -1 & -1 & 1 \\
\hline 2 & 1 & -1 & -1 & 1 & -1 & 3 \\
\hline 3 & 0 & 2 & -2 & 0 & 2 & 2 \\
\hline 4 & 1 & 1 & -1 & -1 & 1 & 3 \\
\hline 5 & 0 & 2 & 2 & 0 & 2 & -2 \\
\hline 6 & 0 & 2 & 0 & 2 & 2 & 0 \\
\hline 7 & 1 & 1 & 1 & 1 & 1 & 1 \\
\hline 8 & -1 & -1 & -1 & -1 & -1 & -1 \\
\hline 9 & 0 & -2 & 0 & -2 & -2 & 0 \\
\hline 10 & 0 & -2 & -2 & 0 & -2 & 2 \\
\hline 11 & -1 & -1 & 1 & 1 & -1 & -3 \\
\hline 12 & 0 & -2 & 2 & 0 & -2 & -2 \\
\hline 13 & -1 & 1 & 1 & -1 & 1 & -3 \\
\hline 14 & -1 & 1 & -1 & 1 & 1 & -1 \\
\hline 15 & 0 & 0 & 0 & 0 & 0 & 0 \\
\hline & & & & & &
\end{tabular}

$$
P(D)=\left(1+2 \cdot D+D^{2}\right) \cdot X(D)
$$

（10）式を周波数成分で表現すると，(11)式となる .

$$
P(f)=4 \cdot \cos ^{2}\left(\pi \frac{f}{f_{R}}\right) \cdot X(f)
$$

ただし， $f_{R}=1 / T_{R}$ である。

(4)式と (11)式とから, $\left\{p_{k}\right\}$ を出力とする等化器の周 波数特性 $E(f)$ は(12)式で表される.

$$
E(f)=\frac{4 \cdot \cos ^{2}\left(\pi \frac{f}{f_{R}}\right)}{U(f)}
$$

なお，ナイキストの標本化定理より， $E(f)=0, f>f_{R} / 2$ でよい。

このようにして得られる $\left(p_{k}, p_{k+1}\right)$ から，これに対応す る信号成分 $\left(x_{0}, x_{1}, x_{2}, x_{3}\right)$ を再生した後, この再生信号に 対応する RLL 符号のビット列を復号するよりも，ビタビ 復号法を用いて $\left\{p_{k}\right\}$ から直接 RLL 符号のビット列を復号 する方が効率が良い. 以下， $\left\{p_{k}\right\}$ に対するビ夕ビ復号法 について示す.

\section{4. ビタビ復号法}

（1）式を用いると，（9)式は(13)式のように書き換えら れる。

$$
p_{k}=b_{k}+b_{k-1}-b_{k-2}-b_{k-3}
$$

(13)式は, いわゆるポリバイポーラと呼ばれるパーシャ ルレスポンス方式の一種であり, 最近 EPR 4 と呼ばれて いる.

本稿では，(13)式で与えられる $p_{k}$ に基づく信号検出方 式をポリバイポーラ検出と呼ぶ。このとき, ビタビ復号器 入力 $z_{k}$ は(14)式で表される.

$$
z_{k}=p_{k}+n_{k}
$$

ここで, 表 4 のように 6 個の状態 $S_{i}(i=0 \sim 5)$ を定める と, $d=2$ を満足する RLL 符号の入出力対応は表 $\mathbf{5}$ に示

表 43 ビットパターンと状態 Assignment of States to 3-bit patterns.

\begin{tabular}{c|c|c|c|c|c|c}
\hline \hline 状態 & $S_{0}$ & $S_{1}$ & $S_{2}$ & $S_{3}$ & $S_{4}$ & $S_{5}$ \\
\hline 3 ビット & 000 & 001 & 011 & 100 & 110 & 111 \\
\hline
\end{tabular}

表 5 状態遷移表

State transition table.

\begin{tabular}{c|c|c|c|c}
\hline \hline \multirow{2}{*}{ 初期状態 } & \multicolumn{2}{|c|}{ 入力 $\left(b_{\mathrm{k}}\right)$} & \multicolumn{2}{c}{ 出力 $\left(p_{\mathrm{k}}\right)$} \\
\cline { 2 - 5 } & 0 & 1 & 0 & 1 \\
\hline$S_{0}$ & $S_{0}$ & $S_{1}$ & 0 & 1 \\
\hline$S_{1}$ & $\times$ & $S_{2}$ & $\times$ & 2 \\
\hline$S_{2}$ & $S_{4}$ & $S_{5}$ & 0 & 1 \\
\hline$S_{3}$ & $S_{0}$ & $S_{1}$ & -1 & 0 \\
\hline$S_{4}$ & $S_{3}$ & $\times$ & -2 & $\times$ \\
\hline$S_{5}$ & $S_{4}$ & $S_{5}$ & -1 & 0 \\
\hline
\end{tabular}


すようになる。表 5 において，×印はこのような状態遷移 は $d$ 制約を満足しないために存在しないことを示す。

また, 図 1 に状態遷移図, 図 2 にはトレリス線図を示す が, 図 1 および図 2 において, 矢印に付した記号は $b_{k} / p_{k}$ を表す。

初期状態が $S(0)$ の長さ $L$ のデータ系列 $\left[b_{1}, b_{2}, \cdots, b_{L}\right]$ に対応する状態遷移図上のパス $\left[S(0) ; b_{1}, b_{2}, \cdots, b_{L}\right]$ が与 えられたときの復号器入力系列 $\left[z_{1}, z_{2}, \cdots, z_{L}\right]$ の負の対数 尤度関数は, ビットセルごとの雑音のサンプル值が互いに 独立であると仮定すると(15)式となる。

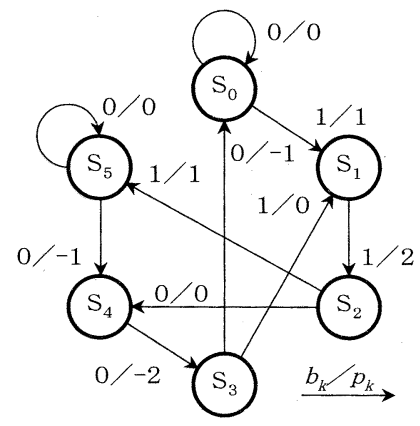

図 $1 d=2$ の RLL 符号に EPR 4 検出を行う場合の状態 遷移図

State transition diagram of a RLL code of $d=2$ with EPR 4 detection.

$$
\begin{aligned}
& -\ln \left[z_{1}, z_{2}, \cdots, z_{L} \mid S(0) ; b_{1}, b_{2}, \cdots, b_{L}\right] \\
& =-\sum_{k=1}^{L} \ln p\left[z_{k} \mid S(k-1) ; b_{k}\right]
\end{aligned}
$$

ここに, $S(k-1)$ は時刻 $(k-1) T_{R}$ にお ける状態 $S_{i}(i=$ 0〜5) を表す.

(15)式により, 与えられたパスの負の対数尤度関数は, パスを構成する個々の枝の負の対数尤度関数の和として表 されることがわかる.したがって, この枝の長さを負の対 数尤度関数で表し, 長さが最小となるパスを選択して, そ れに対応するデー夕系列を出力とすることで最尤系列を復 号できる5).

次に, 上記ビタビ復号法を適用した場合の復号誤り率 を，文献 1)および 2)を参考にして求める。図 3 からわか るように, 復号誤りは復号されたデー夕系列に対応するパ ス(復号パス)が，入力データ系列に対応するパス(正しい パス)から分離した場合に生じる。

正しいパスに対する再生出力系列と, 誤りパスに対する 再生出力系列間のユークリッド距離 $\varepsilon_{q}$ は, 次式により定 義される。

$$
\begin{gathered}
\varepsilon_{q}=\sqrt{\sum_{k=j+1}^{j+q} \varepsilon_{k}^{2}} \\
\text { ここに, } \varepsilon_{k}^{2}=\left(p_{k}-p_{k}^{*}\right)^{2}
\end{gathered}
$$

ただし， $p_{k}$ および $p_{k}^{*}$ は，それぞれ正しいパスと誤りパス

図 2 トレリス線図

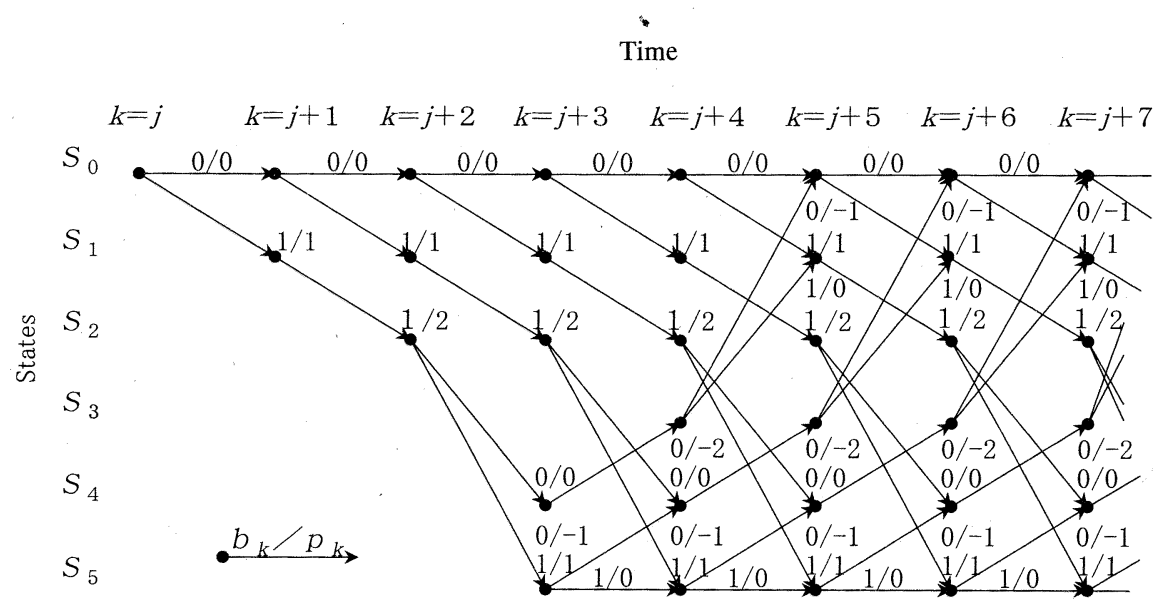

Trelis diagram.

図 3 最小距離を有する誤り事象

Error events of minimum distance.

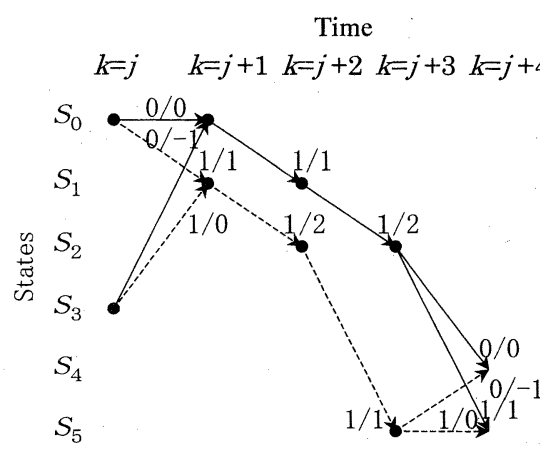

(1) From $S_{0}$ or $S_{3}$

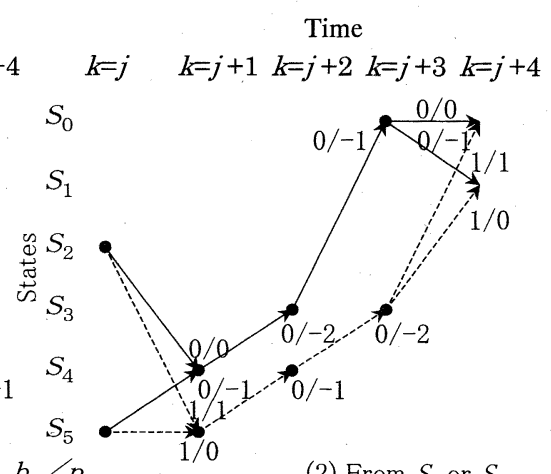

$\stackrel{\stackrel{b_{k} / p_{k}}{\longrightarrow}}{\stackrel{\text { 正しいパス }}{b_{k} / p_{k}} \text { :誤りパス }}$

(2) From $S_{2}$ or $S_{5}$ 
に対する再生出力を表す。

特定の正しいパスが与えられた場合の詋り事象の生起確 率 $p_{e}(q)$ は, 正しいパスの長さおよび誤りパスの長さを求 め, 前者が後者より小となる確率を求めることにより得ら れ，次式となる.

$$
p_{e}(q)=Q\left(\frac{\varepsilon_{q} \cdot a}{2}\right)
$$

ここに, $a$ は再生出力のピーク值と雑音の実効值 $\sigma$ との 比により定義される SN 比であり， $Q(\cdot)$ は，(19)式で定 義される誤差補関数である.

$$
Q(v)=\frac{1}{\sqrt{2 \pi}} \int_{v}^{\infty} e^{\frac{u^{2}}{2}} d u
$$

(18)，(19)式からわかるように, SN 比 $a$ が大のとき は, 最小の $\varepsilon_{q}\left(=\varepsilon_{\min }=2\right)$ の項が誤り事象の生起確率を支 配するので，(18)式は(20)式で近似できる。

$$
p_{e}(q) \cong Q\left(\frac{\varepsilon_{\min } \cdot a}{2}\right)
$$

図 3 亿示すように，最小ユークリッド距離の誤り事象は 8 通りであり,これらにおける溃りビット数はそれぞれ 1 である。また， 0 と 1 の生起確率をそれぞれ 0.5 とする と, 正しいパスの生起確率は $2^{-3}$ である.

さらに，正しいパスと誤りパスを置き換えた場合を考慮 すると, 状態 $S_{j}(j=0,2,3,5)$ で始まる誤り事象の数はそ れぞれ 4 であるから，復号誤り率 $P_{e}$ は次式で近似でき る。

$$
P_{e}=\left\{P\left(S_{0}\right)+P\left(S_{2}\right)+P\left(S_{3}\right)+P\left(S_{5}\right)\right\} \cdot 2^{-3} \cdot 4 \cdot Q(a)
$$

各状態の定常確率 $P\left(S_{i}\right)(i=0 \sim 5)$ はそれぞれ $1 / 6$ にな るので, 復号誤り率は次式で近似できる.

$$
P_{e} \cong \frac{Q(a)}{3}
$$

\section{5. 雑音の白色化}

雑音に相関があるということは，この相関性を利用し て, 過去の雑音から将来の雑音をある程度予測可能である ことを意味する。この予測雑音を真の雑音から除去して残 った雑音は，無相関な，いわゆるランダム雑音にでき，ビ 夕ビ復号器の最適性能が得られる.

この理論的根拠は，スペクトル推定法(6)によってえら れる。例えば，時刻 $k T_{R}$ でのビタビ復号器入力での雑音 のサンプル值を $n_{k}$ とし, 雑音の予測係数を $c_{i}(i=1 \sim L)$ とすると, 予測雑音 $n_{k}$ は (23) 式で与えられる.

$$
\dot{n}_{k}=\sum_{i=1}^{L} c_{i} \cdot n_{k-i}
$$

一方，(12) 式と読出し点での雑音の周波数特性が $N^{\prime}(f)$ であることから, ビ夕ビ復号器入力での等化雑音の自己相 関関数 $\rho(\tau)$ が求まり, 等化雑音の自己相関係数 $R_{i}$ は (24)式で与えられる。なお，(24) 式において $\sigma_{e}^{2}$ は等化雑 音の分散である。

$$
\begin{aligned}
& R_{i}=\rho\left(i \cdot T_{R}\right)=\frac{1}{\sigma_{e}^{2}} \int_{0}^{\frac{f_{R}}{2}}\left|N^{\prime}(f) \cdot \frac{4 \cdot \cos ^{2}\left(\pi \cdot \frac{f}{f_{R}}\right)}{U(f)}\right|^{2} \\
& \cdot \cos \left(2 \cdot \pi \cdot i \cdot \frac{f}{f_{R}}\right) d f
\end{aligned}
$$

(17)式が正しい予測雑音を与えるためには, 予測雑音 $\dot{n}_{k}$ と雑音 $n_{k-j}(j=1 \sim L)$ の相関係数は等しくなければな らず，(25)式が成り立たなければならない.

$$
\begin{aligned}
E\left[\dot{n}_{k} \cdot n_{k-j}\right] & =E\left[\left(\sum_{i=1}^{L} c_{i} \cdot n_{k-i}\right) \cdot n_{k-j}\right] \\
& =\sum_{i=1}^{L} c_{i} \cdot E\left[n_{k-i} \cdot n_{k-j}\right] \\
& =\sum_{i=1}^{L} c_{i} \cdot R_{i-j}=R_{j}
\end{aligned}
$$

ここで, 自己相関関数に関して, 通常 (26) 式の関係が成 り立つから， $L \times L$ 個の自己相関係数よりなる自己相関行 列 $R_{n}$ は，(27)式で表される。

$$
\begin{aligned}
& R_{i-j}=R_{j-i} \\
& \underline{R}_{n}=\left[\begin{array}{cccc}
R_{0} & R_{1} & \cdots & R_{L-1} \\
R_{1} & R_{2} & \cdots & R_{L-2} \\
\vdots & \vdots & \ddots & \vdots \\
R_{L-1} & R_{L-2} & \cdots & R_{0}
\end{array}\right]
\end{aligned}
$$

さらに，L次の係数べクトル $\underline{c}$ を(28)式で表し, 自己 相関係数べクトル $\underline{R}$ を(29)式で表すと，(25)式は(30)式 に書き換えられる。

$$
\begin{aligned}
& \underline{c}=\left(\begin{array}{llll}
c_{1} & c_{2} & \cdots & c_{L}
\end{array}\right) \\
& \underline{R}=\left(\begin{array}{llll}
R_{1} & R_{2} & \cdots & R_{L}
\end{array}\right) \\
& \underline{c} \cdot \underline{R}_{n}=\underline{R}
\end{aligned}
$$

(30)式において， $\underline{R_{n}}$ は正方行列であるから， $R_{n}$ が正則 であれば逆行列 $R_{n}^{-n}$ が存在し，(31)式により雑音予測係 数べクトルcが得られる.

$$
\underline{c}=\underline{R} \cdot \underline{R_{n}^{-1}}
$$

(31) 式と (23) 式とから，統計的性質を満足する雑音予測 が可能になる。このとき, 真の雑音 $n_{k}$ から予測雑音 $\dot{n}_{k}$ を引いた残りの雑音 $n_{k}{ }^{\prime \prime}$ は(32)式で与えられ，この残留 雑音は無相関のいわゆるランダム雑音になる.

$$
n_{k}^{\prime \prime}=n_{k}-\dot{n}_{k}
$$

\section{6. 雑音白色化ビタビ復号法}

(15)式が成り立つような無相関雑音に対するビタビ復号 器は, (15) 式が成り立たない有相関雑音に対して, 最尤系 列を復号できない3).

$d=2$ の RLL 符号にポリバイポーラ検出を用いた場合 のビタビ復号器では，この RLL符号に関する 6 個の状態 $S_{i}(i=0 \sim 5)$ のそれぞれに至る生き残りパスに対応するデ 一夕系列を保持している. したがって, 等化器出力系列 $\left\{z_{k}\right\}$ と, この生き残りパスにより，各生き残りパスに対す る雑音系列 $\left\{n_{h}^{(i)}\right\}(i=0 \sim 5)$ が得られるが, この雑音系列 $\left\{n_{k}^{(i)}\right\}(i=0 \sim 5)$ うち, 真の雑音系列は唯一である. 
真の雑音系列の統計的性質に関しては, 事前に知り得る 本来の雑音の統計的性質と一致する。この場合, 真の雑音 系列から予測した予測雑音系列と, 真の雑音系列との差の 残留雑音はランダムになる。逆に, 誤まった生き残りパス に対する雑音系列の統計的性質は, 本来の雑音の統計的性 質とは一般的に異なることが予想される．このような誤ま った雑音系列に関しては, 本来の雑音の統計的性質を用い て予測した雑音を等化器出力から引くことは, 全体として 雑音を増幅させる働きをし, 当然雑音の相関性も取り除か れない. 以上述べた雑音白色化の原理は，(33)式を具体化 することで実現できる．

$$
\begin{aligned}
& m_{k}\left(S_{0}\right)=\min \left\{m_{k-1}\left(S_{0}\right)-\ln p\left[z_{k}^{(0)} \mid S(k-1)=S_{0} ; b_{k}=0\right],\right. \\
& \left.m_{k-1}\left(S_{3}\right)-\ln p\left[z_{k}^{(3)} \mid S(k-1)=S_{3} ; b_{k}=0\right]\right\} \\
& m_{k}\left(S_{1}\right)=\min \left\{m_{k-1}\left(S_{0}\right)-\ln p\left[z_{k}^{(0)} \mid S(k-1)=S_{0} ; b_{k}=1\right]\right. \text {, } \\
& \left.m_{k-1}\left(S_{3}\right)-\ln p\left[z_{k}^{(3)} \mid S(k-1)=S_{3} ; b_{k}=1\right]\right\} \\
& m_{k}\left(S_{2}\right)=\quad m_{k-1}\left(S_{1}\right)-\ln p\left[z_{k}^{(1)} \mid S(k-1)=S_{1} ; b_{k}=1\right] \\
& m_{k}\left(S_{3}\right)=\quad m_{k-1}\left(S_{4}\right)-\ln p\left[z_{k}^{(4)} \mid S(k-1)=S_{4} ; b_{k}=0\right] \\
& m_{k}\left(S_{4}\right)=\min \left\{m_{k-1}\left(S_{2}\right)-\ln p\left[z_{k}^{(2)} \mid S(k-1)=S_{2} ; b_{k}=0\right]\right. \text {, } \\
& \left.m_{k-1}\left(S_{5}\right)-\ln p\left[z_{k}^{(5)} \mid S(k-1)=S_{5} ; b_{k}=0\right]\right\} \\
& m_{k}\left(S_{5}\right)=\min \left\{m_{k-1}\left(S_{2}\right)-\ln p\left[z_{k}^{(2)} \mid S(k-1)=S_{2} ; b_{k}=1\right]\right. \text {, } \\
& \left.m_{k-1}\left(S_{5}\right)-\ln p\left[z_{k}^{(5)} \mid S(k-1)=S_{5} ; b_{k}=1\right]\right\}
\end{aligned}
$$

ここに，(33)式における $m_{k}\left(S_{i}\right)(i=0,1, \cdots, 5)$ はメトリ ックと呼ばれ, 時刻 $t=k T_{R}$ に扔ける各状態に至るパスの 長さの最小値を表す.また, $z_{k}^{(i)}(i=0 \sim 5)$ は, 等化器出力 $z_{k}$ から, 状態 $S_{i}(i=0 \sim 5)$ に至る生き残りパスに対応する 雑音系列 $\left\{n_{k}^{(i)}\right\}$ を用いて求められる予測雑音 $\dot{n}_{k}^{(i)}$ を引いた
值であり，(34)式で与えられる.

$$
z_{k}^{(i)}=z_{k}-\dot{n}_{k}^{(i)}
$$

予測雑音 $\dot{n}_{k}^{(i)}$ は, 各状態に至る生き残りパスに対応する 雑音系列と (23) 式とから得られる。ここで, 残留雑音を平 均值零, 分散 $\sigma^{2}$ の無相関なガウス雑音と見なすと, (33) 式における各尤度関数はそれぞれ(35)式で表され，(33)式 における各枝の長さは，(36)式で表される.

図 4 に，(33) 式と（36) 式に基づいて構成したビ夕ビ復号 器を示す.

$$
\left.\begin{array}{l}
-\ln p\left[z_{k}^{(0)} \mid S(k-1)=S_{0} ; b_{k}=0\right]=\frac{1}{2} \ln \left(2 \pi \sigma^{2}\right)+\frac{\left(z_{k}^{(0)}\right)^{2}}{2 \sigma^{2}} \\
-\ln p\left[z_{k}^{(0)} \mid S(k-1)=S_{0} ; b_{k}=1\right]=\frac{1}{2} \ln \left(2 n \sigma^{2}\right)+\frac{\left(z_{k}^{(0)}-1\right)^{2}}{2 \sigma^{2}} \\
-\ln p\left[z_{k}^{(1)} \mid S(k-1)=S_{1} ; b_{k}=1\right]=\frac{1}{2} \ln \left(2 \pi \sigma^{2}\right)+\frac{\left(z_{k}^{(1)}-2\right)^{2}}{2 \sigma^{2}} \\
-\ln p\left[z_{k}^{(2)} \mid S(k-1)=S_{2} ; b_{k}=0\right]=\frac{1}{2} \ln \left(2 \pi \sigma^{2}\right)+\frac{\left(z_{k}^{(2)}\right)^{2}}{2 \sigma^{2}} \\
-\ln p\left[z_{p}^{(2)} \mid S(k-1)=S_{2} ; b_{k}=1\right]=\frac{1}{2} \ln \left(2 \pi \sigma^{2}\right)+\frac{\left(z_{k}^{(0)}-1\right)^{2}}{2 \sigma^{2}} \\
-\ln p\left[z_{k}^{(3)} \mid S(k-1)=S_{3} ; b_{k}=0\right] \frac{1}{2} \ln \left(2 \pi \sigma^{2}\right)+\frac{\left(z_{k}^{(3)}+1\right)^{2}}{2 \sigma^{2}} \\
-\ln p\left[z_{p}^{(3)} \mid S(k-1)=S_{3} ; b_{k}=1\right]=\frac{1}{2} \ln \left(2 \pi \sigma^{2}\right)+\frac{\left(z_{k}^{(3)}\right)^{2}}{2 \sigma^{2}} \\
-\ln p\left[z_{k}^{(4)} \mid S(k-1)=S_{4} ; b_{k}=0\right]=\frac{1}{2} \ln \left(2 \pi \sigma^{2}\right)+\frac{\left(z_{k}^{(4)}+2\right)^{2}}{2 \sigma^{2}} \\
-\ln p\left[z_{k}^{(5)} \mid S(k-1)=S_{5} ; b_{k}=0\right]=\frac{1}{2} \ln \left(2 \pi \sigma^{2}\right)+\frac{\left(z_{k}^{(5)}+1\right)^{2}}{2 \sigma^{2}} \\
-\ln p\left[z_{k}^{(5)} \mid S(k-1)=S_{5} ; b_{k}=1\right]=\frac{1}{2} \ln \left(2 \pi \sigma^{2}\right)+\frac{\left(z_{k}^{(5)}\right)^{2}}{2 \sigma^{2}}
\end{array}\right]
$$

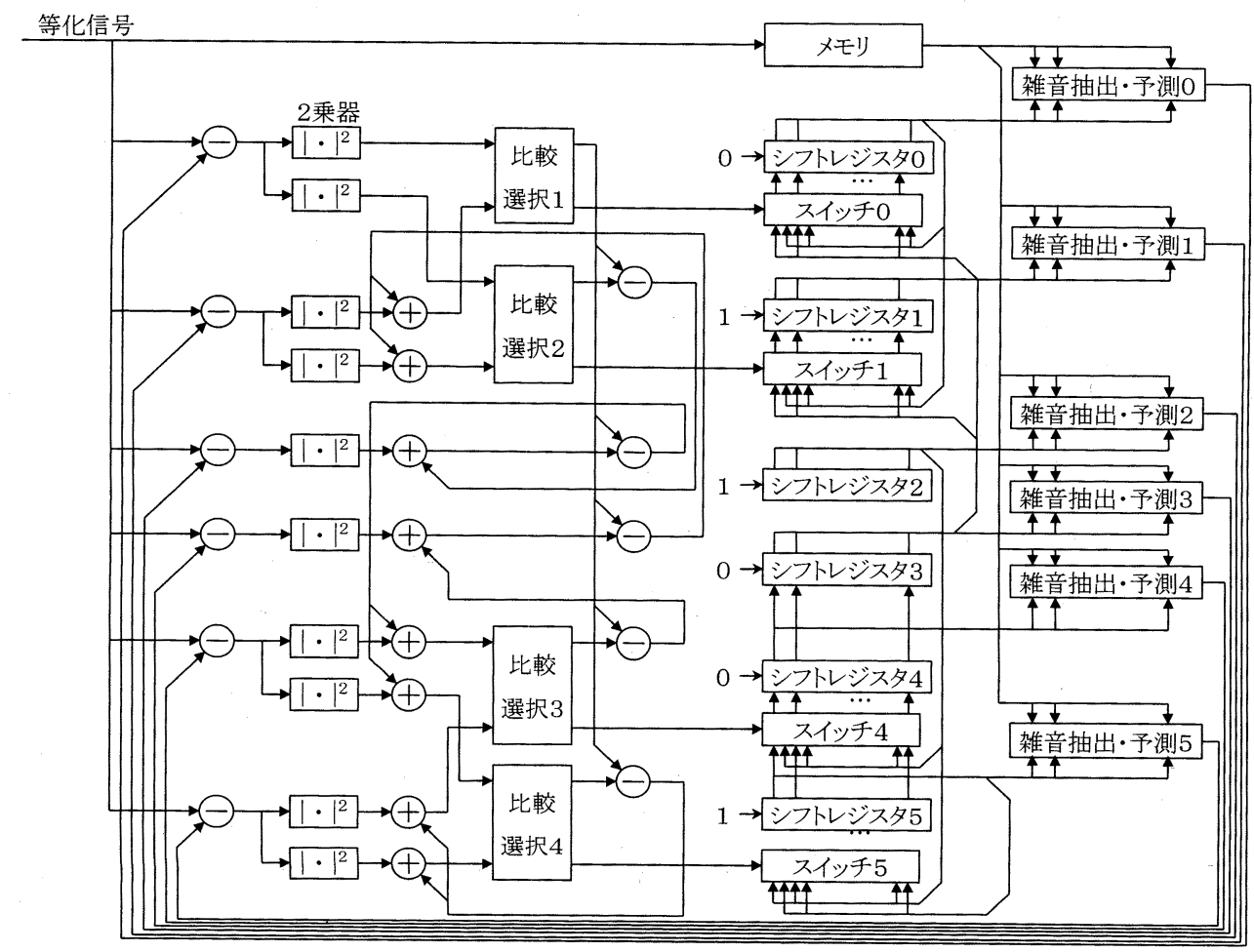

図 4 雑音白色化ビタビ復号器

A Viterbi decoder with noise-whitening function. 


$$
\begin{aligned}
& l_{k}^{(00)}=\left(z_{k}^{(0)}\right)^{2}=\left(z_{k}-n_{k}^{(0)}\right)^{2} \\
& l_{k}^{(01)}=\left(z_{k}^{(0)}-1\right)^{2}=\left(z_{k}-n_{k}^{(0)}-1\right)^{2} \\
& l_{k}^{(12)}=\left(z_{k}^{(1)}-2\right)^{2}=\left(z_{k}-n_{k}^{(1)}-2\right)^{2} \\
& l_{k}^{(24)}=\left(z_{k}^{(2)}\right)^{2}=\left(z_{k}-n_{k}^{(2)}\right)^{2} \\
& l_{k}^{(25)}=\left(z_{k}^{(2)}-1\right)^{2}=\left(z_{k}-n_{k}^{(2)}-1\right)^{2} \\
& l_{k}^{(30)}=\left(z_{k}^{(3)}+1\right)^{2}=\left(z_{k}-n_{k}^{(3)}+1\right)^{2} \\
& l_{k}^{(31)}=\left(z_{k}^{(3)}\right)^{2}=\left(z_{k}-n_{k}^{(3)}\right)^{2} \\
& l_{k}^{(43)}=\left(z_{k}^{(4)}+2\right)^{2}=\left(z_{k}-n_{k}^{(4)}+2\right)^{2} \\
& l_{k}^{(54)}=\left(z_{k}^{(5)}+1\right)^{2}=\left(z_{k}-n_{k}^{(5)}+1\right)^{2} \\
& l_{k}^{(55)}=\left(z_{k}^{(5)}\right)^{2}=\left(z_{k}-n_{k}^{(5)}\right)^{2}
\end{aligned}
$$

図 4 において，等化器からの再生信号は，(14)式に示す 周波数特性を有する。次いで, 減算器群はそれぞれ, 等化 器出力から次の減算を行う.

（1）状態 $S_{0}$ に至る生き残りパスに対応する雑音系列 $\left\{n_{k}^{(0)}\right\}$ から求めた予測雑音 $n_{k}^{(0)}$ の減算.

（2）状態 $S_{1}$ に至る生き残りパスに対応する雑音系列 $\left\{n_{k}^{(1)}\right\}$ から求めた予測雑音 $n_{k}^{(1)}$ の減算.

（3）状態 $S_{2}$ に至る生き残りパスに対応する雑音系列 $\left\{n_{k}^{(2)}\right\}$ から求めた予測雑音 $n_{k}^{(2)}$ の減算.

（4）状態 $S_{3}$ に至る生き残りパスに対応する雑音系列 $\left\{n_{k}^{(3)}\right\}$ から求めた予測雑音 $n_{k}^{(3)}$ の減算.

（5）状態 $S_{4}$ に至る生き残りパスに対応する雑音系列 $\left\{n_{k}^{(4)}\right\}$ から求めた予測雑音 $n_{k}^{(4)}$ の減算.

（6）状態 $S_{5}$ に至る生き残りパスに対応する雑音系列 $\left\{n_{k}^{(5)}\right\}$ から求めた予測雑音 $n_{k}^{(5)}$ の減算.

2 乗器は, (36) 式における $l_{k}^{(00)}, l_{k}^{(01)}, l_{k}^{(30)}, l_{k}^{(31)}, l_{k}^{(12)}, l_{k}^{(43)}$, $l_{k}^{(24)}, l_{k}^{(54)}, l_{k}^{(25)}, l_{k}^{(55)}$ をそれぞれ計算する. 2 乗器に続く加 算器群では，(33)式の加算を実行する.

比較選択はそれぞれ 2 乗器と加算器の出力を比較し, 小 さい方を出力すると共に, 2 乗器の出力を選んだ場合は 2 進值 0 を, 加算器の出力を選んだ場合は 2 進值 1 を出力す る.これら 4 つの比較選択は，(33)式における min 関数 を実現する。

比較選択に続く減算器群では, メトリックのオーバフロ 一を防ぐために設けてあり，これらの出力には新たなメト リック $\dot{m}_{k}\left(S_{i}\right)(i=0 \sim 5)$ が現れる.この場合, $\dot{m}_{k}\left(S_{0}\right)$ は ゼロであるから，(33)式の $\dot{m}_{k}\left(S_{0}\right)$ の項を省略できるの で, 2 乗器の出力と比較選択 1 の出力との加算器は必要な い.

シフトレジスタ $i(i=0 \sim 5)$ は, 各状態 $S_{i}(i=0 \sim 5)$ に至 る生き残りパスに対応するビット列を保持し，スイッチ 0 と 1 および 4 と 5 は, 生き残りパスに対応するビット列を 順次更新するために，シフトレジスタ間のコピー経路を形 成する。

メモリは, 直近の連続する $q$ 個の等化器出力を常に保 持している. 雑音抽出・予測はそれぞれ, メモリの出力と 各シフトレジスタの出力から得られる状態 $S_{j}(j=0 \sim 5) に$ 至る生き残りパスに対応する $q$ 個の理想的な再生出力か ら, 状態 $S_{j}$ に至る生き残りパスに対応する $q$ 個の雑音 $n_{k+i}^{(j)}(i=0 \sim q-1)$ を求め, これらの雑音と(23)式により 予測雑音 $\dot{n}_{k+i}^{(j)}$ を算出する。

これらの予測雑音 $\dot{n}_{k+i}^{(j)}$ は, 先に示したように, 減算器 を用いて等化器の出力から引かれ, 上述の動作を繰り返 す.この結果, 雑音の相関は除去され, 最尤復号系列が得 られる復号器を実現できる.

\section{7. 実験結果}

$d=2$ の RLL 符号である $8 / 12$ 符号7)を用いた場合の， 従来のビタビ復号器の誤り率を 1 としたときの, 雑音白色 化ビタビ復号器 (図 4) との相対比較結果を図 5 に示すとと もに，誤り率を比較した条件を以下に記す。

[実験条件]

・テープ/ヘッド間速度約 $7.5 \mathrm{~m} / \mathrm{s}$ のディジタルビデオテ ープレコーダの試作機を使用.

・ $8 / 12$ 符号の記録レートは $40.5 \mathrm{Mb} / \mathrm{s}$.

[実験方法]

・孤立再生波形をコンピュータに取り込み，伝達特性 $U(f)$ を算出.

・無記録状態のテープ再生信号をコンピュータに取り込

み，等化器出力での雑音の周波数特性を算出.

・雑音白色化ビタビ復号器の雑音予測段数は 4 .

・6144 ビットよりなる 8/12 符号で符号化したブロックを くり返し記録.

[評価方法]

・テープ上の異なる 16 カ所から, 1 カ所当たり 42 ブロッ ク分の等化器出力でのデータをコンピュータに取り込 み。

・コンピュータ上に, 共にソフトウェアで構成した従来の ビタビ復号器と, 雑音白色化ビタビ復号器について, コンピュータに取り込んだ同一のデータに対して, 誤 り率を比較 (16 種類).

・ 16 種類のデータ全部に関する平均誤り率を比較.

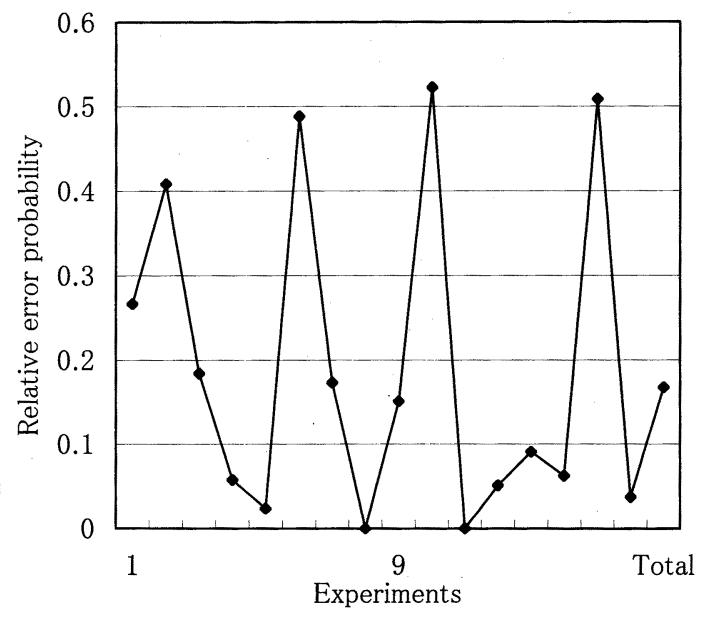

図 5 愦り率の相対比較 Comparison of error probabilities. 
図 5 から, 雑音白色化ビタビ復号器の方が, 平均で約 $1 / 6$ 亿愦り率が改善されていることがわかる。な扔, 従来 のビタビ復号器の誤り率の平均值は, 約 $3 \times 10^{-4}$ である.

今回の実験では, バーストエラーを除外して評価してい ない.したがって，媒体の欠損などによる10２0ビット 程度の非常に短いバーストエラーが, 図 5 に示す誤り率改 善効果のばらつきの一因である可能性がある.

事実, 従来のビ夕ビ復号器および雑音白色化ビ夕ビ復号 器ともに, 特定の同一ブロックに䛤りが集中する場合が散 見されたが，この要因の詳細な解析は今後の課題である.

なお，バーストエラーに対しては，雑音白色化ビ夕ビ復 号法の効果は期待できないが, 逆に, バーストエラーの少 ない媒体では，更に高い改善効果が期待できる。

\section{8.むすび}

本論文では, ビ夕ビ復号器の最適性能を実現することを 目的とし, ビタビ復号器の性能を損なう要因のひとつであ る等化によって生じる雑音の相関を除去する方法について 検討した。

この結果, NRZL 表記で $d=2$ の RLL符号のひとつで ある $8 / 12$ 符号を用いた場合，雑音の相関を利用した雑音 予測をビ夕ビ復号器に導入することで, 通常のビ夕ビ復号 器に比べて，詔り率を約 $1 / 6$ に低減することができた．

今後, 自動等化のような雑音の特性がダイナミックに変 化する場合の雑音予測方法や，雑音予測を高速に処理する
ための実現技術について更に検討する必要がある。

終わりに，日頃ご指導ご鞭撻いただく愛媛大学 田崎三 郎教授，有益なご討論をいただいた愛媛大学 大沢寿教授， 岡本好弘助教授および当社越後紀康主任技師, 水島哲也 主任技師，松見知代子主任技師ならびに太田潤技師に深謝 する。

\section{〔文献〕}

1) Kobayashi: "Application of Probabilistic Decoding to Digital Magnetic Recording System”, IBM J. Res. \& Dev., 15, pp. 64-74 (Jan. 1971)

2）大沢寿, 田崎三郎, 池谷章: “NRZI 型記録方式に対するビタビ復号法の 適用について”, 信学論, 63-C, pp. 353-360（June 1980）

3）大沢寿, 池谷章, 田崎三郎: “NRZL 記録符号に対するビタビ復号法の信 号検出方式に関する性能比較”, テレビ誌, 35, 7, pp. 570-575 (1981)

4）猪瀬博, 宮川洋: “PCM 通信の進歩”, 産報, 東京, pp. 279-326 (1974)

5）池谷章：“等化・復号装置”, 特許公開公報, 特開平 1-222541 (1989)

6）有本卓：“信号・画像のディジタル処理”, 産業図書, 東京 (1980)

7）池谷章：“符号変換装置” , 特許公開公報, 特開昭 62-36088 (1987)

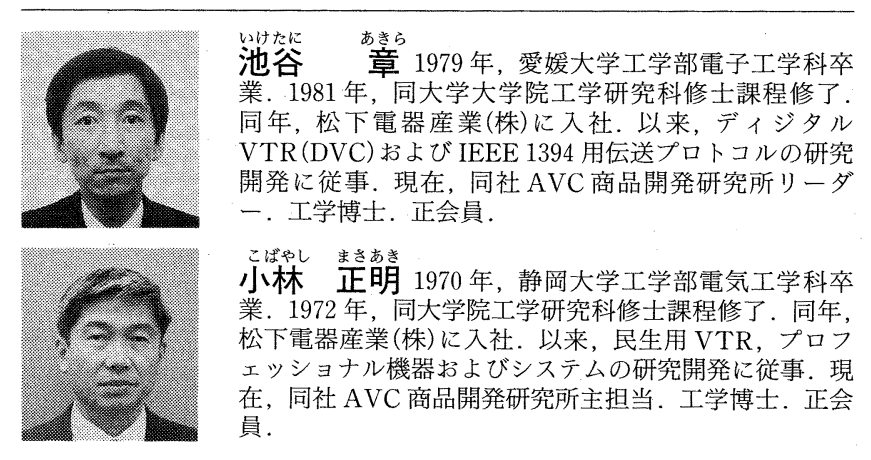

